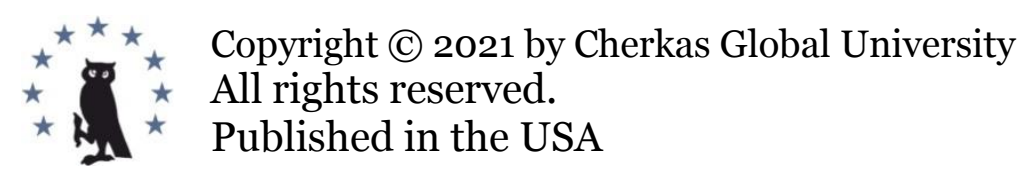

European Journal of Contemporary Education

E-ISSN 2305-6746

2021. 10(4): 969-980

DOI: 10.13187/ejced.2021.4.969

https://ejce.cherkasgu.press

IMPORTANT NOTICE! Any copying, reproduction, distribution, republication (in whole or in part), or otherwise commercial use of this work in violation of the author(s) rights will be prosecuted in accordance with international law. The use of hyperlinks to the work will not be considered copyright infringement.

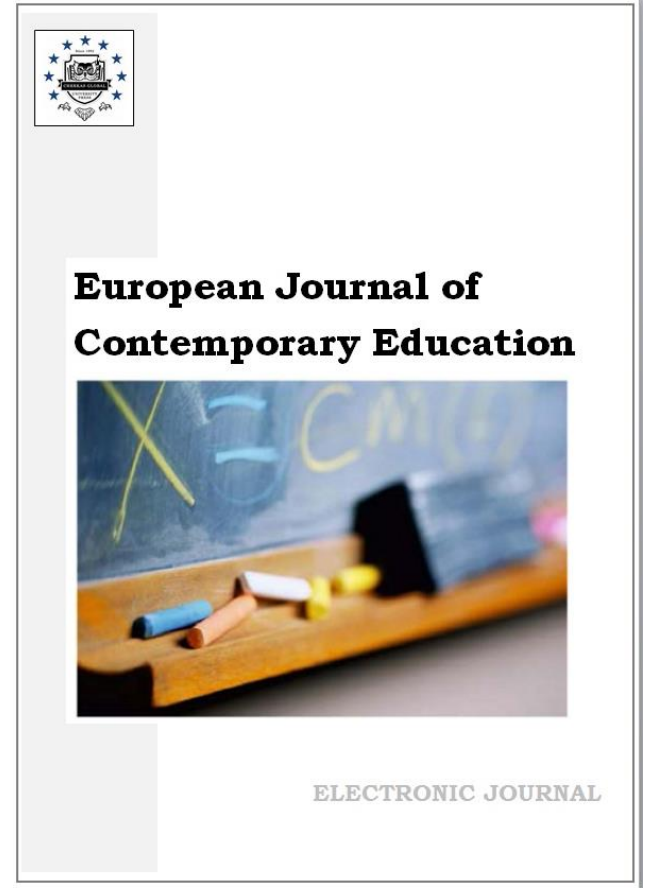

\title{
Technologically Supported Infusion of 21st century Skills Development within 21 Days
}

Andrii E. Lebid a, b , *, Alla Krasulia a, Olena Sushkova a, Natal'ya A. Shevchenko b, c

a Sumy State University, Sumy, Ukraine

b Cherkas Global University, Washington, USA

c Volgograd State University, Volgograd, Russian Federation

\begin{abstract}
The article aims to study the mechanisms of formation and development of soft skills, taking into account top technology trends and the digitalization of higher education. Based on the analysis of best world practices in soft skills development, the article's authors conclude that transferable skills are fundamental to the formation of professional competencies. This conclusion has become possible based on a thorough theoretical review and self-report questionnaire findings.

The article describes implementing a 21-day-skill-acquisition teaching technique to form and develop students' hard and soft skills. The intervention conducted at the Department of Germanic Philology, Faculty of Foreign Philology and Social Communications, Sumy State University,

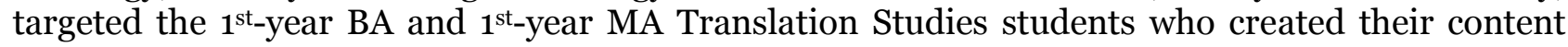
using modern video blogging technology.

The research findings make it possible to conclude that the development of soft skills significantly determines students' personal trajectory of learning and acquiring professional competencies.

Keywords: educational technology, soft skills, transversal competencies, digital pedagogy, education digitalization, learning environment, Education for Sustainable Development (ESD), education reform, academic governance.
\end{abstract}

\section{Introduction}

The modern global economy, which is at the stage of a new technological order, the 4th Industrial Revolution, requires the combined efforts of all those who are more or less involved

\footnotetext{
* Corresponding author

E-mail addresses: a.lebid@socio.sumdu.edu.ua (A. Lebid)
} 
in the professional training of future specialists and highly qualified personnel. In addition, such collaboration provides for systematic intellectual intervention in developing professional and transversal competencies, soft skills, and abilities with a broad application of information and information and communication technology (ICT) in training and learning.

Considering this, the purpose and objectives of modern education are in harmony with the top technology trends and digitalization of the world economy. In such conditions, it is essential to expand the formats of providing educational services, the methods, mechanisms, and ways of training a modern specialist that meets the requirements and demands of the current labour market.

Given this, each university should consider the tasks and challenges that arise in technologydriven professions and a shift in emphasis on the hard and soff skills, and transversal competencies of university graduates. It will allow them to perform professional functions upon graduation, open up broad prospects for self-actualization in the profession, further education, and self-paced study. Implementing this goal in modern conditions is impossible without supplementing the fundamental theoretical training of university students with high-quality, practical/hands on training.

Educators can provide such a combination only by introducing a model of innovative, digital pedagogy into the educational process. Its task is learning and gaining knowledge, nurturing professional competencies, forming and developing super-professional non-specialized skills, particularly communication, (meta)cognition, self-regulation, etc. Besides, the world's leading universities' positive experience is worth studying and applying at the national level of higher education.

The modern higher education system responds directly to these challenges and trends, improving its programs and courses, considering the changing global situation. Based on this, world universities are interested in the formation and development of transversal skills of their graduates: analytical thinking and innovation, critical thinking and analysis, active learning and learning strategies, complex problem-solving, etc. (HPD, 2021); time management and development of training strategies, planning, design, analysis, and expertise skills (DCE, 2021); intellectual, communication, organizational, and research proposals skills (SPUC, 2021; DSS YU, 2021), etc.

Thus, in the constantly changing global economic conditions, taking into account the trend towards its global digitalization, the national education system at all its levels also needs a meaningful transformation. The determinant of such changes is the challenges and demands of the modern global labour market associated with the structural modifications of many professions and activities. Therefore, the correlation of the content and form of training, their compliance with the current requirements is in demand (WEF, 2016; Tytler, et al., 2019).

\section{Materials and methods}

During the preparation of the manuscript, we analyzed data from open educational platforms and resources of the world's leading universities (Harvard, Oxford, Yale, Cambridge, etc.) to familiarize ourselves with the program competencies of graduates of these educational institutions. We studied the formation of these competencies in the context of the development of transversal skills in courses and disciplines offered by university curricula.

As a methodological component of the study, we used the 21-day learning technique. Fact is that forming a particular habit requires 21 days, that is, repeating a specific action under these conditions for three weeks in a row.

Surgeon Maxwell Maltz coined this idea in his book Psychocybernetics, which modern scientists have received many confirmations. During a series of experiments, it was found out that it takes an average of about 66 days to acquire a habit, while this value can vary from 18 to 254 days, depending on the individual characteristics of a person.

We have elaborated and practically implemented an educational project "A 21-day Speaking (Vlogging) Challenge" on the educational platform GRAASP (https://graasp.eu/) to create personal learning spaces i.e. vlogs. That challenge was a 21-step intensive course aimed at improving effective public speaking and presentation skills, as well as digital literacy, self-regulation, creativity, critical thinking, collaboration, and communication, and was based on gamification principles.

The 1st-year students in the Germanic Philology Department at Sumy State University, Ukraine, were exposed to a vlogging experience and then asked to express their thoughts on incorporating this teaching technique into the language classroom. 
The results of a survey of the Sumy State University students (Faculty of Foreign Philology and Social Communications), carried out using Google Forms of online surveys and polls, were used for preparation of the article. A Google Form survey was created by the researchers to obtain participants' responses. The sample included 32 Philology students (14 undergraduate and 18 postgraduate students) enrolled in the Faculty of Foreign Philology and Social Communications, Sumy State University, Ukraine. The study was based on the Pearson's $\chi^{2}$ criterion as nonparametric methods of assessing the significance of differences between actually observed and expected results.

\section{Discussion}

For many years in a row, the central theme of the annual WEF in Davos has been education, skills development, and lifelong learning. As the participants of the panel discussions noted, in the context of accelerating the digital transformation of jobs and the risk of their loss, there are issues of accelerated retraining, advanced training, and training, providing new skills for the global workforce. While simultaneously reforming the content of education and its compliance with the professions of the future.

According to the speakers, the future of jobs is not necessarily drastic, but now there are significant changes in the skill set in each profession that will exist in the future, and the so-called soft skills will be crucial in the long run. So, we need a revolution in learning - the forum participants came to this conclusion (WEF, 2020).

Both teachers and scientists noted the relevance and necessity of forming and developing super-professional skills of educational applicants, particularly noting that soft skills are critical in interpersonal communication and their further application in everyday practice (England et al., 2020; Fernandez, Liu, 2019).

Some researchers emphasize the dilemma and difficulties of developing professional and soft skills at the same time. In their opinion, an effective mechanism for their development is problembased learning (PBL) with elements of developing and implementing their software project, which makes it possible to develop cognitive, communication, leadership, and other soft skills (Tadjer et al., 2020).

Several researchers note the importance of developing soft skills in the context of increased competition in the labour market while emphasizing the need for close cooperation between teachers, university graduates, and employers to work as effectively as possible on forming such skills (Dolce et al., 2020).

An essential component of the development of soft skills is the gamification of learning and the use of simulation models in the educational process. These tools allow you to maximize the formation of super-professional skills following global experience in the context of international education. Experimental learning through role-playing games is recognized as the best way to improve soft skills (Levant et al., 2016; Holohan, 2019).

The use of mobile pedagogy and information and communication technologies (ICT) is also effective in the learning process. They get more impactful in blended learning when developing professional and super-professional skills, particularly communication skills, self-regulation and selfdevelopment, design, analysis, expertise, etc. (Krasulia, Saks, 2020; Stal, Paliwoda-Pękosz, 2019).

Project-based learning give students the opportunity to form and develop transversal skills. Besides, using problem solving as a teaching strategy can engage students in developing deep understanding of important concepts and principles, developing soft skill and appropriate competencies (Chassidim et al., 2018; Blythe et al., 2019). With such competencies, being inexperienced specialists, students are more independent and focused on productivity, which makes cooperation with them more interesting (Lebid, Shevchenko, 2020b).

We observe the corresponding trends in our own teaching experience. It provides non-financial methods of motivation for the managerial staff and novice specialists (Lebid, Shevchenko, 2020b). An essential component of project-based learning is the development of communication, leadership, organizational and teamwork skills. Based on the combination of classical models of blended learning and interactive digital technologies in the educational process, an integrated model is proposed by several Ukrainian researchers, i.e. a traditional classroom model is integrated with the project approach to provide ways for collaborative problem solving (Marchenko et al., 2021). 
As the experience of using various educational technologies shows, the formation and development of soft skills significantly affect reflection and self-regulation processes, promoting multiple types of self-management activities in the format of entrepreneurship and new corporate versions of self-presentation. Developing soft skills in this context is seen by some researchers as the "chances of putting yourself first" to present yourself favourably in a professional environment advancing your career growth (Fixsen et al., 2018).

In recent years, many universities have been involved in revising their curricula, mainly adapting to rapid changes in technology and more general efforts to improve teaching. However, some scholars believe that legal pedagogy has disproportionately focused on the traditional "lawyer thinking" model. At the same time, it should promote the "lawyer feeling" model by helping students hone soft skills such as empathy, honesty, problem-solving, etc. Law schools can encourage law teachers to create a more inclusive student learning environment by systematically implementing such teaching techniques. Overall, soft skills training can significantly improve the experience of students and teachers in law education (Tsaoussi, 2020).

Eventually, it is worth mentioning the development of cognitive skills that are especially in demand in the business environment, decision-making processes, media activities, etc. (Varela, 2020; Lebid, Shevchenko, 2020b; Lebid, Shevchenko, 2020c).

\section{Results}

It is worth saying that a rapidly growing body of theoretical research on educational technology proves that it helps educators elaborate personalized, authentic, dynamic, social, selfregulated learning potentially available anytime, anywhere. It is clear from the literature that pedagogical understanding was not developed at the same speed that the devices were handed out to students. What seems to be the reality in university classrooms globally, particularly in Ukraine, is that even though educational technology is being used, it is not providing the intended learning outcomes at the same rate that these technologies are being incorporated into the everyday classroom experience. There is a gap in our knowledge of what is happening with technology and learning for students.

Students today, who are called digital natives, are apt at using technology. Tools such as laptops, smartphones, and tablets are already second nature to them. Taking technology out of the learning equation would be removing an integral part of the students' abilities. Likewise, even if the student is not already technology-savvy, that's even more of a reason to embrace the skill. Understanding technology is becoming more and more critical in the workplace and other areas. But digital innovations can be a source of challenges for university students and faculty as well.

Let us now move on to the educational tools that we used in the framework of the pedagogical experiment described in the paper to engage students in the online environment to develop their hard skills and transversal competences.

The teaching materials and tasks were aimed at improving four foundational language skills (reading, writing, listening, and speaking) some soft skills, and transversal competences. A social media platform GRAASP was used to support learning activities along the way. The primary purpose of the intervention was to ensure that every student experiences 21st-century learning. It means the project emphasized the 4Cs (Critical Thinking, Communication, Collaboration, and Creativity).

From our perspective, if you want to engage students and ensure that they are learning and have mastered specific hard and soft skills, you need to get them to the point where they are creating content. So, the students were involved in a 21-Day Speaking (Vlogging) Challenge during the academic semester. It was a 21-step intensive EFL course to develop their speaking, presentation, digital literacy, and self-regulation skills daily.

The first days seemed to make the most significant difference, so it was worth trying to be particularly diligent at the beginning of the attempted-habit-acquisition process. According to the research, three weeks/21 days is a minimum period to build a new habit. On average, it takes more than two months before a new behavior becomes automatic, 66 days to be exact.

So, to develop students' speaking and presentation skills, we integrated video blogging (i.e., a video blog or video $\log$, vlog (/vlng/)) to support the EFL learning experience outside the classroom. The students were supposed to make short videos and start their vlog (for educational purposes only). Vlog entries often combine an embedded video (or a video link) with supporting 
text, images, and other metadata. Entries can be recorded in one take or cut into multiple parts. In recent years, "vlogging" has spawned a large community on social media, becoming one of the most popular forms of digital entertainment.

It is popularly believed that, alongside being entertaining, vlogs can deliver deep context through imagery instead of written blogs. But in terms of our classes, students were posting their vlogs on a social learning platform GRAASP. It is an agile, versatile and comprehensive resource for creating, exploiting, sharing personal learning spaces which support collaborative and inquirybased learning.

Students could choose from different types of Vlogs, e.g.: (1) Personal Vlog is an online video that records an individual to deliver information that they intend to introduce to people; (2) Live broadcasting Vlogs established by YouTube and other social platforms such as Instagram and Facebook; (3) Informative Vlogs are designed to educate the viewer about a particular subject; (4) Bereavement Vlogs are aimed to express feelings of loss, grief, and mourning; (5) Conversational Vlogs are rather formal and create a civil discussion; (6) Motovlog is created while riding a motorcycle, etc.

To create a vlog, students had to follow the instructions: (1) create a theme and a purpose for a vlog; (2) name their vlogs; (3) prepare the content; (4) record a video; (5) post and share their video blogs with their classmates and teacher on Graasp; (6) keep their vlogs updated; (7) comment on their peers' vlogs.

Meanwhile, it is worth highlighting some essential points in more detail. There are three main stages that students should pass to make a proper vlog with a fluent speech. The first stage of making a vlog is preparation. Here, they think over the subject of the video, its content, the suitable editing video software, and, if necessary, some background music. When choosing a topic, they should consider the key demands: the matter should be up-to-date, engaging, and valuable for their peers; they should avoid rude or low colloquial words. In this stage, students also concentrate on how to make their speech accurate and fluent.

They start to write scripts, read them out loud, and practice enunciation. Reading the script several times will give them the confidence to deliver the speech properly without looking at the notes. As they say, 'Sharing is caring'. And it is in the second stage when they can upload and share their vlogs on GRAASP. In the third stage, they get feedback through comments from the teacher and peers daily within three weeks' time.

Upon the project completion, we collected qualitative and quantitative data via a self-report questionnaire to maximize the reliability and validity of the study. We want to draw your attention to the research findings that helped us construct a holistic picture of what we observed. The qualitative and quantitative analyses revealed that even though students reported on several technical constraints and digital literacy challenges (Figure 1), their overall learning experience was positive.

What difficulties did you have while creating your video project?

14 відповідей
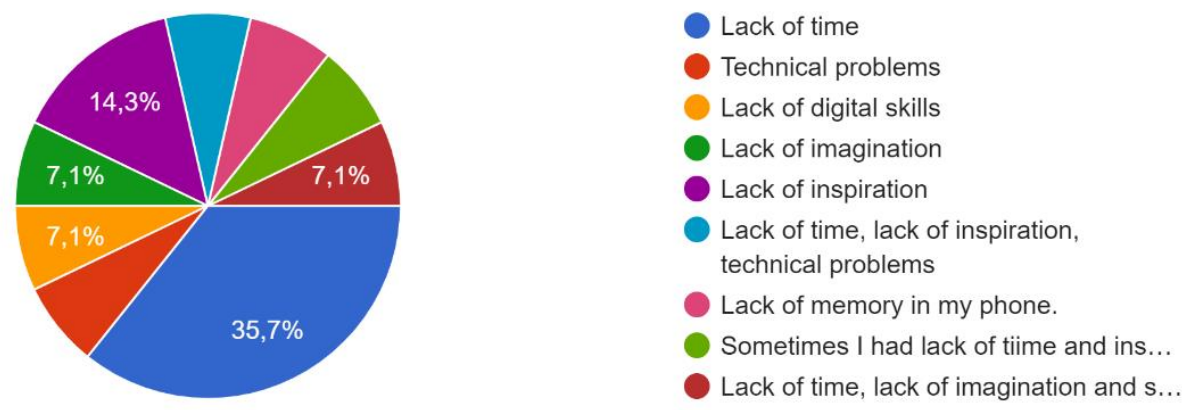

Fig. 1. What difficulties did you have while creating you video project

Most of the students indicated that they had contributed to their English language learning during the study and fostered their soft skills enjoying a more absorbing and engaging learning 
process. Our ultimate goal was to replicate an authentic experience, promote collaboration, creativity, and self-regulation, and increase the desire to speak and communicate.

Half of the students consider that participation in the "21-Day Vlogging Challenge" improved their self-reflection (Figure 2).

Do you think that participation in the "21-Day Vlogging Challenge" improved your self-reflection?

14 відповідей

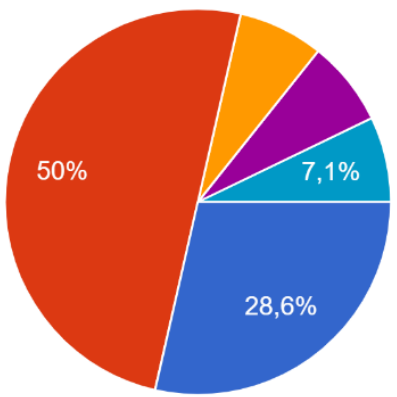

Certainly yes

More likely yes than no

More likely no than yes

Certainly no

More likely yes than no, because I don't feel so picky about my behavior in front of the camera.

Certainly yes, because I had a chance to see my work from different prospective, and realized where are $\mathrm{m} . .$.

Fig. 2. Do you think that participation in the "21-Day Vlogging Challenge" improved your self-reflection?

The same percentage was very self-critical about their pronunciation. Still, to improve their intonation and pronunciation, students used various learning strategies, such as practicing tonguetwisters, highlighting the stressed words, marking stresses and melody of the English language. Thus, we can conclude that the students fostered their self-regulation skills day in and day out (Figure 3).

How do you perceive your intonation and pronunciation when you hear yourself?

14 відповідей

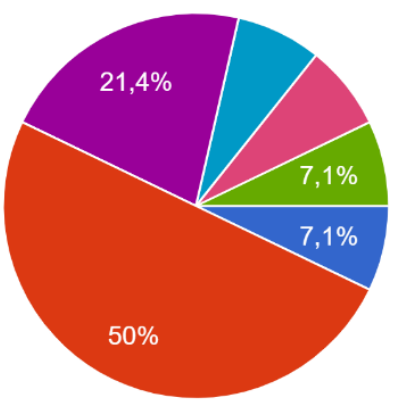

I like it

It could be better

I don't really like it but it is OK

Awfully, I can't stand it

I was trying to improve it every time

I can say that it become much better if compare with the day when we first $m$..

I like it. Moreover I liked that I could watch my skills develop during the ch...

I was trying to improve it, but even no..

Fig. 3. How do you perceive your intonation and pronunciation when you hear yourself?

Here is one more piece of evidence of a high level of student engagement and, consequently, continuous self-regulation and digital literacy skills development. The fact that they would have taken part in the challenge even if they had known about an incentive such as extra points to get a higher grade in the semester (Figure 4) speaks for itself. 
If you knew about an incentive or a perk, like a prize or a bonus or extra points to get a higher grade, BEFORE you started the Challenge, would it affect your participation rate?

14 відповідей

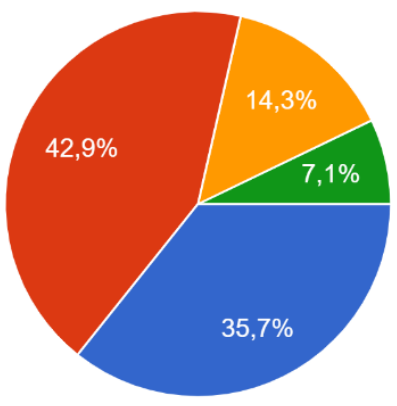

Yes, it would. I really lacked intrinsic motivation, so it would have been great if I had known about a perk in advance.

No, it would not. I was highly motivated to partake in the challenge without any external stimulus.

Not sure about it.

I'm not sure, because maybe the competition did not affect the habit, but the desire to win and some of the parti...

Fig. 4. If you knew about an incentive or a perk, like a prize or a bonus or extra points to get a higher grade, BEFORE you started the Challenge, would it affect your participation rate?

All in all, the challenge helped them become more confident to speak in front of the camera and be more fluent in English (Figure 5).

Did the Challenge help you become a little bit more confident to speak in front of the camera and be more fluent in English?

14 відповідей

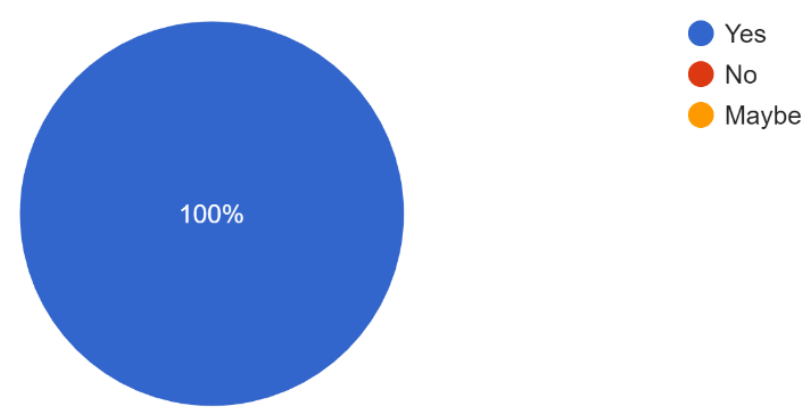

Fig. 5. Did the Challenge help you become a little bit more confident to speak in front of the camera and be more fluent in English?

One of the open-ended questions of the questionnaire, which reads "What kind of habits have you managed to incorporate into your life upon completing the Challenge?" enriched the study with the following data:

Student 1: 'I think I developed a habit of getting things done on time, not postponing everything till the last minute.'

Student 2: "When I stand in front of the bathroom mirror or cook something, I start to say something in English. Sometimes I imagine that I am a beauty or food blogger and I express my thoughts in English.'

Student 3: 'I acquired a habit of elaborating a topic every evening, rehearsing the script, shooting the video, then editing it and uploading it to the platform.'

Student 4: 'Throughout the day, I was thinking about the topic to present. In addition to that, I was filming interesting things, which I added to my videos later on.'

Student 5: 'This challenge helped me to manage time wisely. Besides, now I have a habit of reading something new about the cinematographic industry.'

Student 6: 'I have leart to do everything here and now, and also be more organized.' 
Student 7: 'I practice tongue-twisters every day, and it seems to me that my speech melody and rhythm have become more 'English'-like.'

Student 8: 'I don't think I was responsible during the Challenge, so I didn't incorporate any new habits into my life.'

Student 9: 'Sometimes I start speaking in English and don't notice it. I also got used to shooting videos, so now I feel strange that I do not have to do it anymore'.

Student 10: 'Now I have a habit not to procrastinate. I have become more punctual and do everything on time.'

Student 11: 'I have practiced speaking in front of the camera, even if I make mistakes. Before the vlogging challenge, I used to have some psychological blocks, and I was too shy to speak in public or in front of the camera.'

Student 12: 'I incorporated the habit of thinking in English, which I consider extremely important for my further improvement.'

Student 13: 'I became a little less afraid of the camera and a bit more self-confident. I hope I improved my pronunciation and self-regulation.'

Student 14: 'Upon completing the Challenge, I have managed to incorporate a skill of speaking English every day, and to learn new vocabulary. Besides, I loved to watch my groupmates' videos, communicate with them and get to know their opinions about my vlog'.

The present study aimed to replicate an authentic real-life experience, foster students' creativity and self-regulation, and increase their desire to speak and communicate. Assumably, its success became possible due to the design of enriching language learning experiences. The study findings proved that incorporating creative, challenging tasks raised students' overall satisfaction with EdTech in EFL learning and nurturing transversal skills.

Table 1. Observed results

\begin{tabular}{|l|c|c|c|}
\hline \multirow{2}{*}{ Factorial Feature } & \multicolumn{3}{c|}{ Observed Outcomes } \\
\cline { 2 - 4 } & $\begin{array}{c}\text { Undergraduates } \\
\text { (BA) }\end{array}$ & $\begin{array}{c}\text { Postgraduates } \\
\text { (MA) }\end{array}$ & Total \\
\hline Participated in the Vlogging Challenge & 14 & 17 & $\mathbf{3 1}$ \\
\hline $\begin{array}{l}\text { Participation in the Challenge improved my } \\
\text { soft skills }\end{array}$ & 12 & 17 & $\mathbf{2 9}$ \\
\hline In total & 26 & 34 & $\mathbf{6 0}$ \\
\hline
\end{tabular}

Table 2. Expected results

\begin{tabular}{|l|c|c|c|}
\hline \multirow{2}{*}{ Factorial Feature } & \multicolumn{3}{|c|}{ Expected Outcomes } \\
\cline { 2 - 4 } & $\begin{array}{c}\text { Undergraduates } \\
\text { (BA) }\end{array}$ & $\begin{array}{c}\text { Postgraduates } \\
\text { (MA) }\end{array}$ & Total \\
\hline Participated in the Vlogging Challenge & 13 & 17 & $\mathbf{3 0}$ \\
\hline $\begin{array}{l}\text { Participation in the Challenge improved my } \\
\text { soft skills }\end{array}$ & 12 & 16 & $\mathbf{2 8}$ \\
\hline In total & 25 & 33 & $\mathbf{5 8}$ \\
\hline
\end{tabular}

Based on the observed and expected results (Table 1; Table 2) we stated a null hypothesis: $\mathrm{H}_{\mathrm{o}}$ - Vlogging is an effective educational tool that fosters both undergraduate and graduate students' soft skills development.

Upon using the formula to calculate $\chi^{2}$,

$$
\chi_{n}^{2}=\sum_{i=1}^{n} \frac{\left(O_{i}-E_{i}\right)^{2}}{E_{i}}
$$

we got the following results: the chi-square calculated value is 0.087 . The correlation of the factorial features and the outcome is statistically insignificant, the level of significance is $\mathrm{p}>0.05$ $(\mathrm{p}=$ 0.768). Therefore, it indicates strong evidence for the null hypothesis, i.e. technologically 
supported infusion of the 21-st century skills development within 21 days is effective for both BA and MA students.

The following are students' responses about their experience of participating in the 21-Day Vlogging Challenge. They illustrate how the participants perceived the use of Vlogging on the online platform Graasp with teaching-learning activities to nurture and grow their soft skills.

«I liked the idea of talking about music and sharing my favourite pieces. I was glad to know that we have the same music tastes with some of my groupmates! Besides, vlogging was not only good because I could share my ideas with others, but I developed editing skills as well.

The biggest advantage was that I had to speak English every day. I also liked that I opened up in front of the camera and felt like a speaker.

I really like the YouTube platform, because it's basically a free cinema, a platform where you can find anything.

So it was very interesting to be a part of this process. Try to become a vlogger for 21 days.

The advantages are that you become more open, easier to respond to the camera. This is a cool advantage to develop your speech.

It has always been my dream to try vlogging, so it was a perfect opportunity to try it and, in addition to this, improve my speaking skills.

It the most simple way to show your way of thinking, to tell everything that you want and how you want. So the best thing is that you are free to chose what are you going to do.

Personally for me it's a self-expression. It is the most wonderful way to show yourself, to convey your ideas and thoughts to the public.

It helps you to self-reflect and improve your speaking skills.

You can hear your voice, pronounciation so you can understand your mistakes and correct them. I like the process of editing the most. English

I liked that I can improve my pronunciation and see how I look like when I am talking in

I liked to improve my pronunciation skills, we talked about what interests us. skills.

I liked the most that I could share with my peers thoughts about series and train my speaking

I reckon that the most I liked the opportunity to share my thoughts and practice my speaking skills.

The greatest thing is that I could choose topics by myself

In my opinion, the advantages of vlogging are improving your speeking skills and sharing your thoughts and views with the audience. Personally, I liked when I saw views and likes on my video, in another words feedback. It was very important and sweet for me».

The following examples are some data taken from the survey that show how time consuming and technically challenging the attempted-habit-acquisition process can be.

«The main disadvantage might be that daily vlogging is a huge drain on your time, especially if you edit your videos. Besides, it takes a lot of your energy. Sometimes I felt like a squeezed lemon after posting a video.

Sometimes I shot a video when everyone at home was already asleep that's why I had to talk quietly. But sometimes someone forgot that I was shooting a video and because of different sounds I had to reshoot something.

There are no disadvantages. It's just a lack of time to make the video better and longer. Maybe more interesting. Also, the realization that it needs to be done every day is a little scary :) in the early days.

It was difficult to find the time an energy to make videos every day.

The one thing that can be challenging is technical issues, but in general it's a great way to improve your skills.

The lack of time. Sometimes. But this issue can be solved.

Being honest, I think it's just not my thing, I had no pleasure in it, every time I told myself that I just have to do it and then I'll be free.

It really takes a lot of time and energy.

That you need to use your mobile memory so I had a lack of it and also I had some techincal problems 

faster.

At first I didn't like video editing, it took a lot of time, and then I learned how to do editing

I did not like that I should be all the time with access to the Internet and that sometimes I just had not inspiration and good mood for vlogging and I think sometimes it influenced on the quality of video.

I didn't really like that I had to spend plenty of time for making the videos

The main disadvantage is that it took too much time. To create one 2-minute video I had to spend about an hour.

Vlogging takes a lot of time and you should put in your best licks to make a good video, but still you can face the condemnation from others but personally I have not encountered this».

\section{Conclusion}

Summarizing the research findings, we can draw certain conclusions, in particular, that information and communication technologies (ICT) enable educators:

develop students' hard and soft skills and transversal competencies;

create comfortable conditions for learning anywhere and anytime, particularly in the times of the COVID-19 pandemic;

diversify teaching methods and techniques;

stimulate students' motivation to life-long learning;

The main components of technologically supported infusion of 21-st century skills development within 21 days are:

Motivated students;

A professional creative teacher;

Authentic, real-world teaching/learning resources;

Interactive educational technologies.

Thus, the effective diffusion of all the above mentioned components allows students to develop creative and intellectual abilities collaboratively, form their digital and presentation skills, foster their transversal competences. Therefore, apply university classroom knowledge on the job.

\section{Limitations}

The study has some limitations. The present study is without a control group, and it is harder to be certain that the outcome was caused by the experimental treatment and not by other variables. The second limitation of the present research is that we relied on a single survey and comparison one group's outcomes before and after a treatment has not been provided.

\section{References}

Blythe et al., 2019 - Blythe, K., Solomon, J., Gunther, W. (2019). The Hard Task of Soft Skills: Project Management for the Materials Review Process. Serials Review. 45(3): 158-159.

Chassidim et al., 2018 - Chassidim, H., Almog,. D., Mark, S. (2018). Fostering soft skills in project-oriented learning within an agile atmosphere. European Journal of Engineering Education. 43(4): 638-650.

DCE, 2021 - University of Oxford. Department for continuing education. [Electronic resource]. URL: https://www.conted.ox.ac.uk/

Dolce et al., 2020 - Dolce, V., Emanuel, F., Cisi, M., Ghislieri, C. (2020). The soft skills of accounting graduates: perceptions versus expectations. Accounting Education. 29(1): 57-76.

DSS YU, 2021 - Yale University. Developing Soft Skills. [Electronic resource]. URL: https://your.yale.edu/work-yale/learn-and-grow/training/clerical-technical-training-and-developme nt/developing-soft-skills

England et al., 2020 - England, T., Nagel, G., Salter, S. (2020). Using collaborative learning to develop students' soft skills. Journal of Education for Business. 95(2): 106-114.

Fernandez, Liu, 2019 - Fernandez, F., Liu, H. (2019). Examining relationships between soft skills and occupational outcomes among U.S. adults with - and without - university degrees. Journal of Education and Work. 32(8): 650-664. 
Fixsen et al., 2018 - Fixsen, A., Cranfield, S., Ridge, D. (2018). Self-care and entrepreneurism: an ethnography of soft skills development for higher education staff. Studies in Continuing Education. (40)2: 181-197.

Holohan, 2019 - Holohan, A. (2019). Transformative Training in Soft Skills for Peacekeepers: Gaming for Peace. International Peacekeeping. 26(5): 556-578.

Hora et al,. 2018 - Hora, M., Benbow, R., Smolarek, B. (2018). Re-thinking Soft Skills and Student Employability: A New Paradigm for Undergraduate Education. Change: The Magazine of Higher Learning. 50(6): 30-37.

HPD, 2021 - Harvard University Professional Development (2021). 10 Emerging Skills for Professionals. [Electronic resource]. URL: https://professional.dce.harvard.edu/blog/10-emergingskills-for-professionals/

Krasulia, 2021 - Krasulia, A. (2021). Developing EFL Students' Speaking Skills: 21-Day Vlog Challenge. III Annual Conference on Current Foreign Languages Teaching Issues in Higher Education: Conference Proceedings of the International Scientific and Practical Conference. Pp. 70-73.

Krasulia, 2020 - Krasulia, A. (2020). The Convergence of Technology, Pedagogy, and Language Learning. Implementatsiia yevropeiskykh standartiv v ukrainski osvitni doslidzhennia: materialy IV Mizhnarodnoi naukovoi konferentsii Ukrainskoi asotsiatsii doslidnykiv osvity. Drohobych: TzOV "Trek-LTD". Pp. 80-83.

Krasulia, Pistor, 2021 - Krasulia, A., Pistor, P. (2021). Virtual internationalisation - how COIL and other models can support cross-border exchange. The Internationalisation of Higher Education Perspectives from the THEA Ukraine Project and Beyond. Petra Pistor (Ed.). FH Münster, pp. 98-110.

Krasulia, A., Saks, 2020 - Krasulia, A., Saks, K. (2020). Students' perceptions towards mobile learning in an English as a foreign language class. IEEE 2oth International Conference on Advanced Learning Technologies. ICALT. Pp. 238-240.

Lebid et al., 2020a - Lebid, A., Degtyarev, S.I., Polyakova, L.G. (2020). A Study into the Skills of Using Data Verification Tools as a Media Information Literacy Instrument for University Students. International Journal of Media and Information Literacy. 5(2): 184-190.

Lebid, Shevchenko, 2020b - Lebid, A., Shevchenko, N. (2020). Cultivation of the Skills of Design Thinking via the Project-Based Method as a Component of the Dual Model of Learning. European Journal of Contemporary Education. 9(3): 570-581.

Lebid, Shevchenko, 2020c - Lebid, A., Shevchenko, N. (2020). Cultivating the Skills of Systems Thinking in the Context of Fostering the Basic and Professional Competencies Associated with Media Education and Media Literacy. International Journal of Media and Information Literacy. 5(1): 60-68.

Lebid, Shevchenko, 2020d - Lebid, A., Shevchenko, N. (2020). Gender Differentiation in Perceiving and Evaluating the Interactive Methods of Education by the Engineering Students. European Journal of Contemporary Education. 9(4): 819-826.

Levant et al., 2016 - Levant, Y., Coulmont, M., Sandu, R. (2016). Business simulation as an active learning activity for developing soft skills. Accounting Education. 25(4): 368-395.

Marchenko et al., 2021 - Marchenko, A., Antypenko, V., Vashchenko, S., Fedotova, N., Chybiriak Y., Krasulia, A. (2021). A Complex Model of Blended Learning: Using a Project Approach to Organize the Educational Process. Information and Software Technologies. Pp. 265-278.

Pellegrino et al., 2012 - Pellegrino, J.W., Hilton, M.L. (2012). Education for Life and Work: Developing Transferable Knowledge and Skills in the Twenty-First Century. Washington, DC: National Academies Press, $257 \mathrm{p}$.

SPUC, 2021 - University of Cambridge. Skills portal: [Electronic resource]. URL: https://www.transkills.admin.cam.ac.uk/skills-portal

Stal, Paliwoda-Pękosz, 2019 - Stal, J., Paliwoda-Pękosz, G. (2019). Fostering development of soft skills in ICT curricula: a case of a transition economy. Information Technology for Development. 25(2): 250-274.

Tadjer et al., 2020 - Tadjer H., Lafifi Y., Seridi-Bouchelaghem H., Gülseçen, S. (2020). Improving soft skills based on students' traces in problem-based learning environments. Interactive Learning Environments. 
Tsaoussi, 2020 - Tsaoussi, A. (2020). Using soft skills courses to inspire law teachers: a new methodology for a more humanistic legal education. Law Teacher. 54(1): 1-30.

Tytler, et al., 2019 - Tytler, R., Bridgstock, R. et al. (2019). 100 jobs of the future. Report. Deakin University, $81 \mathrm{p}$.

Varela, 2020 - Varela, O. (2020). Teaching core soft skills into business curriculum: Can we teach longitudinally? Journal of Education for Business. 95(3): 180-192.

WEF, 2016 - World Economic Forum. The Future of Jobs Employment, Skills and Workforce Strategy for the Fourth Industrial Revolution. Global Challenge Insight Report. Geneva. The World Economic Forum, 2016. 167 p.

WEF, 2020 - World Economic Forum. Education, Skills and LifelongLearning. [Electronic resource]. URL:https://www.weforum.org/events/the-jobs-reset-summit-2020/themes/education-sk ills-and-lifelong-learning 